\title{
Editor's letter
}

ere's a brief introduction to the articles and the authors in Volume 47, Number 6 of Strategy \& Leadership:

B. Joseph Pine II, a co-founder of Strategic Horizons LLP is the author of a number of groundbreaking books on strategic marketing including Mass Customization, The Experience Economy \& Authenticity and Infinite Possibility: Creating Customer Value on the Digital Frontier. His article "Customering: the mindset of a revolutionary model" explains how "Customering seeks to create a customized offering that meets the individual wants, needs and desires of each particular customer, both at a specific moment in time and on into a future relationship."

Stephen Denning is the author of The Leader's Guide to Radical Management and The Age of Agile. His article "How Amazon uses metrics to drive success" recounts how "At Amazon, metrics are established in advance of every activity and specify what actions are expected to happen in ways that can be measured in real-time."

V.K. Narayanan is the Deloitte Touche Jones Stubbs Professor of Strategy \& Entrepreneurship, Management Department at Drexel University. His article "Using institutional knowledge to answer puzzling questions about novel challenges and opportunities" describes how "Institutional knowledge is crucial to the effectiveness of an organization because it enables it to reduce the time and effort needed to explore a novel challenge."

In his interview "Scott Kupor explains the new realities of accessing venture capital" he offers insights into how VCs assess startup teams. "Why is this particular team best positioned to win the market versus any of the others that might approach the same opportunity? The team in many ways can become more important than the original business idea, particularly since we know the market and product will evolve over time." His interviewer, Alistair Davidson, a contributing editor to Strategy \& Leadership, has been CEO of a number of startup businesses.

Open source innovation researchers and consultants John Winsor, Jin Paik, Mike Tushman and Karim Lakhani are affiliated with the Laboratory for Innovation Science at Harvard and Harvard Business School. Their article "Overcoming cultural resistance to open source innovation" suggests that "Open systems become more appealing when we position these services as tools that let the employees bring in some of the latest and greatest technologies that they can use to advance their original idea and project."

For their article "The future of banking in the platform economy," IBM researchers and consultants Sarah Diamond, Nick Drury, Anthony Lipp, Anthony Marshall, Shanker Ramamurthy and Likhit Wagle surveyed 850 senior banking executives worldwide and found that "Visionary banks believe engagement with partners across platforms should increase their commitment to innovation, especially relating to the search for new and more valuable product and service combinations." They identified strategies to help banks reorganize the way they do business to compete successfully in this new age of cross-industry platform business models.

Good reading!

Robert M. Randall

Editor

Strategy \& Leadership 